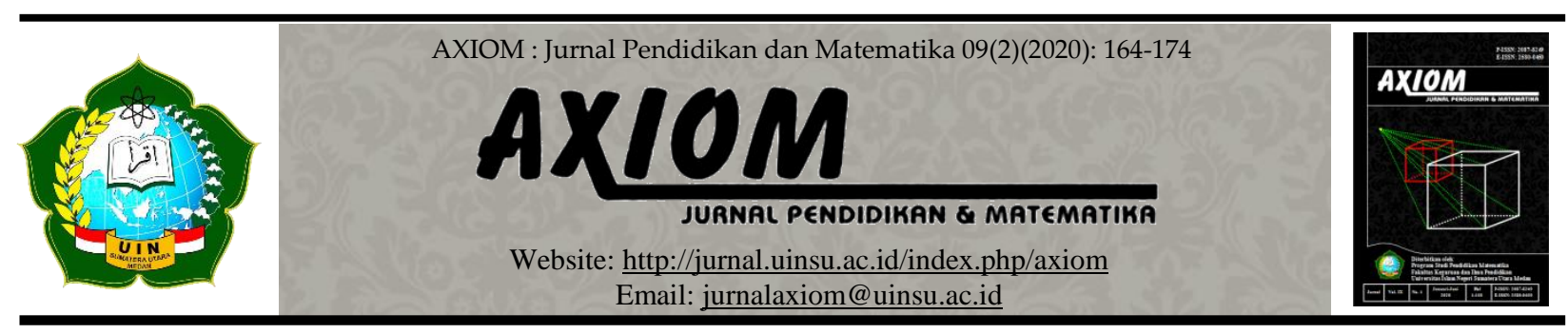

\title{
PERBEDAAN KEMAMPUAN PENALARAN DAN KOMUNIKASI MATEMATIS SISWA YANG DIAJAR DENGAN MODEL PEMBELAJARAN KOOPERATIF TIPE THINK PAIR SHARE (TPS) DAN GROUP INVESTIGATION (GI)
}

Oleh:

\author{
Fibri Rakhmawati ${ }^{1}$, Wisnu Syahputra ${ }^{2}$, \\ ${ }^{1}$ Pendidikan Matematika, Fakultas Ilmu Tarbiyah dan Keguruan, Universitas Islam Negeri \\ Sumatera Utara \\ ${ }^{2}$ Pendidikan Matematika, Fakultas Ilmu Tarbiyah dan Keguruan, Universitas Islam Negeri \\ Sumatera Utara \\ E-mail: ${ }^{1}$ fibree.r@gmail.com, ${ }^{2}$ wisnusyahputra1712@gmail.com
}

doi : 10.30821/axiom.v9i2.8021

\begin{abstract}
Abstrak:
Penelitian ini bertujuan untuk mengetahui perbedaan kemampuan penalaran dan kemampuan komunikasi matematis siswa yang diajar dengan model pembelajaraan kooperatif tipe Think Pair Share (TPS) dan Group Investigation (GI). Penelitian ini adalah penelitian kuantitatif, dengan jenis penelitian quasi eksperimen. Populasinya adalah seluruh siswa kelas XI MIA MAN 1 Medan tahun ajaran 2018-2019 yang berjumlah 372 siswa. Sampel yang digunakan oleh peneliti adalah kelas XI MIA 6 dan XI MIA 7 yang masing-masing berjumlah 45 siswa untuk dijadikan kelas eksperimen yang ditentukan dengan cara Cluster Random Sampling. Pengumpulan data dilakukan dengan menggunakan instrumen kemampuan penalaran dan kemampuan komunikasi matematis siswa. Analisis data dilakukan dengan analisis varian (ANAVA) dan kemudian dilanjutkan dengan Uji Tuckey. Hasil temuan ini menunjukkan: (1) Terdapat perbedaan kemampuan penalaran dan kemampuan komunikasi matematis siswa yang diajar dengan model pembelajaran kooperatif tipe TPS dan GI Materi Pokok Integral Kelas XI MIA MAN 1 Medan; (2) Terdapat perbedaan kemampuan penalaran matematis siswa yang diajar dengan model pembelajaran kooperatif tipe TPS dan GI Materi Pokok Integral Kelas XI MIA MAN 1 Medan; (3) Tidak terdapat perbedaan kemampuan komunikasi matematis siswa yang diajar dengan model pembelajaran kooperatif tipe TPS dan GI Materi Pokok Integral Kelas XI MIA MAN 1 Medan; (4) Tidak terdapat interaksi yang signifikan antara model pembelajaran yang digunakan terhadap kemampuan penalaran dan kemampuan komunikasi matematis siswa. Simpulan penelitian ini menjelaskan bahwa kemampuan penalaran dan kemampuan komunikasi matematis siswa lebih baik diajarkan dengan model pembelajaran kooperatif tipe TPS daripada dengan model pembelajaran kooperatif tipe GI.
\end{abstract}

Kata Kunci:

Kemampuan penalaran matematis, komunikasi matematis, Think Pair Share (TPS), Group Investigation (GI)

\section{Abstract:}

This study aims to determine the differences in reasoning abilities and mathematical communication skills of students who are taught with the Think Pair Share (TPS) and Group Investigation (GI). This research is a quantitative research, with the type of quasi-experimental 
research. The population was all students of class XI MIA MAN 1 Medan for the 2018-2019 academic year, totaling 372 students. The sample used by the researcher was class XI MIA 6 and XI MIA 7, each of which totaled 45 students to be used as an experimental class which was determined by means of cluster random sampling. The data was collected using instruments of students' reasoning abilities and mathematical communication skills. Data analysis was performed with analysis of variance (ANOVA) and then continued with the Tuckey Test. The results of these findings indicate: (1) There are differences in reasoning abilities and mathematical communication skills of students taught by cooperative learning models TPS and GI type Integral Subject Class XI MIA MAN 1 Medan; (2) There are differences in students' mathematical reasoning abilities taught by the cooperative learning model type TPS and GI Integral Subject Class XI MIA MAN 1 Medan; (3) There is no difference in the mathematical communication skills of students who are taught with the cooperative learning model type TPS and GI Integral Subject Class XI MIA MAN 1 Medan; (4) There is no significant interaction between the learning model used on students' reasoning abilities and mathematical communication skills. The conclusion of this study explains that students' mathematical reasoning and communication skills are better taught with the TPS-type cooperative learning model than with the GI-type cooperative learning model.

\section{Keywords:}

Mathematical reasoning skills, mathematical communication, Think Pair Share (TPS), Group Investigation (GI)

\section{A. Pendahuluan}

Matematika merupakan salah satu pelajaran yang menduduki peran penting dalam pendidikan. Hal ini terbukti dari lebih banyaknya jam pelajaran matematika yang otomatis mendominasi pelajaran-pelajaran lain yang ada di sekolah. Matematika juga sangat besar peranannya dalam kehidupan sehari-hari, maka dari itu matematika sudah diajarkan dari jenjang pendidikan yang paling rendah, dimulai dari sekolah dasar, sekolah menengah pertama, sekolah menengah atas sampai dengan perguruan tinggi.

Pembelajaran matematika yang diberikan di sekolah harus dapat mengasah siswa agar mereka memiliki kompetensi dasar dalam matematika sesuai dengan tujuan umun pembelajaran matematika. NCTM (2000) menyatakan bahwa terdapat lima kemampuan matematis yang harus dikuasi siswa melalui pembelajaran matematika, yaitu: (1) pemecahan masalah (problem solving), (2) penalaran dan pembuktian (reasoning and proof), (3) koneksi (connection), (4) komunikasi (communication), (5) representasi (representation). Fondasi dari matematika adalah penalaran (reasoning), salah satu tujuan terpenting dari pembelajaran matematika adalah mengajarkan kepada siswa penalaran logika (logical reasoning). Bila kemampuan bernalar tidak dikembangkan pada siswa, maka bagi siswa matematika hanya akan menjadi materi yang mengikuti serangkaian prosedur dan meniru contoh-contoh tanpa mengetahui maknanya (Sugianto, 2014: 116). Selain kemampuan penalaran, siswa harus memiliki kemampuan komunikasi matematis untuk meningkatkan pemahaman siswa terhadap matematika. Kemampuan komunikasi matematis tidak hanya sekedar menyatakan ide tertulis tetapi lebih luas lagi, yaitu merupakan bagian kemampuan siswa dalam hal menyatakan, menjelaskan, menggambarkan, mendengar, menanyakan dan bekerjasama.

Namun, pada kenyataannya yang terlihat berdasarkan studi pendahuluan di lapangan dengan salah seorang guru mata pelajaran matematika masih banyak siswa yang kurang dalam kemampuan penalaran dan kemampuan komunikasi matematis. Hal ini terbukti siswa sulit menjelaskan kembali materi yang sudah dipelajari ketika guru meminta kepada siswa untuk menjelaskan kembali materi yang sudah di jelaskan guru dan kurang mampunya siswa dalam menyelesaikan soal yang membutuhkan penalaran. Maka dari itu, diperlukan strategi pembelajaran agar dapat meningkatkan kemampuan penalaran dan kemampuan komunikasi matematis siswa. Salah satu model yang tengah populer dikalangan pendidikan adalah model pembelajaran kooperatif. Think Pair Share (TPS) dan Group Investigation (GI) adalah termasuk tipe pembelajaran kooperatif. Menurut Istarani (2012: 68) ada bebarapa kelebihan 
Fibri Rakhmawati \& Wisnu Syahputra: Perbedaan Kemamupuan Penalaran dan Komunikasi Matematis Siswa yang Diajar dengan Model Pembelajaran Kooperatif Tipe Think Pair Share (TPS) dan Group Investigation (GI)

TPS yaitu dapat meningkatkan daya nalar siswa, daya kritis siswa, daya imajinasi siswa, daya analisis terhadap suatu permasalahan dan dapat memningkatkan kemampuan siswa dalam menyampaikan pendapat sebagai implementasi ilmu pengetahuannya. Sedangkan salah satu kelebihan GI adalah dapat melatih siswa memiliki kemampuan yang baik dalam berkomunikasi dan mengemukakan pendapatnya (Kurniasih \& Sani, 2015). Sehingga penulis tertarik untuk meneliti model pembelajaran kooperatif tipe TPS dan GI untuk meningkatkan kemampuan penalaran dan kemampuan komunikasi matematis siswa

Tujuan penelitian adalah untuk mengetahui perbedaan kemampuan penalaran dan komunikasi matematis siswa yang diajar dengan model pembelajaraan kooperatif tipe TPS dengan GI; mengetahui perbedaan kemampuan penalaran matematis siswa yang diajar dengan model pembelajaran kooperatif tipe TPS dan GI; mengetahui perbedaan kemampuan komunikasi matematis siswa yang diajar dengan model pembelajaran kooperatif tipe TPS dan GI.

\section{B. Kajian Teoritis}

\section{Kemampuan Penalaran Matematis}

Hendriana, Rohaeti, dan Sumarmo (2017: 26) menyatakan bahwa dalam matematika, penalaran matematis adalah proses berfikir matematik dalam memperoleh kesimpulan matematis berdasarkan fakta atau data, konsep, dan metode yang tersedia atau yang relevan. Penalaran matematis sangat penting yang harus dimiliki siswa dalam membantu siswa tidak sekedar mengingat fakta, aturan, dan langkah-langkah penyelesaian masalah, tetapi menggunakan ketrampilan bernalarnya dalam melakukan pendugaan dalam menelaah soal sehingga yang bersangkutan akan memperoleh pemahaman konsep matematika yang saling berkaitan. Ciri-ciri penalaran matematis adalah: (a) adanya suatu pola pikir yang disebut logika. Berpikir logis diartikan sebagai berpikir menurut suatu pola tertentu atau menurut logika tertentu, dan (b) proses berpikirnya bersifat analitik dan menggunkan logika.

Menurut NCTM (2000) standar penalaran matematik meliputi (a) mengenal penalaran sebagai aspek mendasar dari matematika; (b) membuat dan menyelidiki dugaan matematik; (c) mengembangkan dan mengevaluasi argument matematik; dan (d) memilih dan menggunakan berbagai tipe penalaran. Sehubungan dengan itu, dorongan dan kesempatan yang didapat anak di kelas untuk melakukan penalaran dalam kerangka memecahan masalah matematik merupakan fondasi yang diperlukan untuk mencapai standar penalaran yang dirumuskan NCTM tersebut. Dan indikator penalaran matematika terjadi ketika siswa sedang: (a) mengamati pola, (b) menemukan generalisasi dan konjektur berkenaan dengan keteraturan yang diamati, (c) menilai/menguji konjektur, (d) mengkonstruk dan menilai argumen matematika, dan (e) menggambarkan atau memvalidasi konklusi logis tentang sejumlah ide dan keterkaitannya.

\section{Kemampuan Komunikasi Matematis}

Ramdani (2012: 47) menyatakan bahwa kemampuan berkomunikasi adalah penting dalam semua disiplin ilmu dan dunia kerja, artinya bahwa seseorang harus dapat: (1) Membuat konsep, (2) mengkomunikasikan mathematical thinking mereka secara koheren (tersusun secara logis) dan jelas kepada teman-temanya, guru, dan orang lain, (3) menganalisis dan menilai mathematical thinking dan strategi yang dipakai orang lain, dan (4) menggunakan bahasa matematika untuk mengekspresikan ide-ide matematika secara benar.

Handayani (2014: 3) menyatakan bahwa kemampuan komunikasi yang bersifat matematika atau yang lebih dikenal dengan komunikasi matematis dapat diartikan sebagai kemampuan dalam menyampaikan sesuatu yang diketahuinya melalui dialog pembicaraan atau tulisan tentang apa yang mereka kerjakan, misalnya berupa konsep, rumus, atau strategi penyelesaian masalah dalam matematika. Kemampuan komunikasi matematis tersebut merefleksikan pemahaman peserta didik dan guru bisa membimbing peserta didik dalam penemuan konsep serta mengetahui sejauh mana peserta didik mengerti tentang materi pelajaran matematika. 
Menurut Hasratuddin $(2015,19)$ terdapat lima aspek yang termasuk ke dalam kemampuan komunikasi, kelima aspek yang dimaksud adalah: (1) representasi (representing); yang meliputi menunjukkan kembali suatu idea atau masalah dalam bentuk baru, misalnya menerjemahkan masalah kedalam bentuk kongkrit dengan bagan atau gambar, menyajikan persoalan atau masalah kedalam model matematika yang berupa diagram, persamaan atau pertidaksamaan matematika, grafik, tabel, atau sejumlah kalimat yang sederhana; (2) mendengar (listening). Dalam proses pembelajaran yang melibatkan diskusi, aspek mendengar merupakan salah satu aspek yang sangat penting. Dalam proses ini, kemampuan siswa dalam memberikan pendapat atau komentar sangat terkait dengan kemampuan dalam mendengarkan topik-topik utama atau konsep-konsep esensial yang didiskusikan. Pentingnya mendengar secara kritis juga dapat mendorong siswa berpikir tentang jawaban pertanyaan sambil mendengar; (3) membaca (reading). Dalam membaca matematika, Bell berpendapat bahwa yang menjadi penyebab kesulitan siswa dalam belajar matematika adalah lemahnya kemampuan membaca secara umum, dan ketidakmampuan membaca secara khusus. Sebab matematika merupakan ilmu yang bahasanya syarat akan simbol dan istilah; (4) diskusi (discussing). Kegiatan diskusi merupakan sarana bagi seseorang untuk dapat mengungkapkan dan merefleksikan pikiran pikirannya. Menguraikan beberapa kelebihan dari diskusi kelas, yaitu antara lain: Dapat mempercepat pemahaman materi pembelajaran dan kemahiran menggunakan strategi, membantu siswa mengkonstruk pemahaman matematis, menginformasikan bahwa para ahli matematika biasanya tidak memecahkan masalah sendiri-sendiri, tetapi membangun ide bersama pakar lainnya dalam satu tim, dan membantu siswa menganalis dan memecahkan masalah secara bijaksana; (5) menulis (writing), merupakan sebuah kegiatan yang dilakukan dengan sadar untuk mengungkapkan dan merefleksikan pikiran. Menulis adalah alat yang bermanfaat dari berpikir karena siswa memperoleh pengalaman matematika sebagai suatu aktivitas yang kreatif. Selain itu, menulis juga dapat meningkatkan taraf berpikir siswa ke arah yang lebih tinggi.

\section{Model Pembelajaran Kooperatif}

Rasyidin dan Nur (2011: 153) menayatakan bahwa pembelajaran kooperatif (cooperatif learning) merupakan salah satu cara yang dapat digunakan di dalam proses pembelajaran, dimana para peserta didik bekerja sama dalam kelompok-kelompok kecil dan diberikan penghargaan atas keberhasilan kelompoknya. Menurut Sanjaya (dalam Rusman, 2014), cooperative learning merupakan kegiatan belajar siswa yang dilakukan dengan cara berkelompok. Model pembelajaran kelompok adalah rangkaian kegiatan belajar yang dilakukan oleh siswa dalam kelompok-kelompok tertentu untuk mencapai tujuan pembelajaran yang telah dirumuskan. Dan menurut Johnson (dalam Rusman, 2014), cooperative learning adalah teknik pengelompokan yang di dalamnya siswa bekerja terarah pada tujuan belajar bersama dengan kelompok kecil yang umumnya terdiri dari 4-5 orang.

Trianto (2014: 109) menyatakan bahwa belajar kooperatif dapat mengembangkan solidaritas sosial dikalangan siswa. Dengan belajar kooperatif, diharapkan kelak akan muncul generasi baru yang memiliki hasil akademik yang cemerlang dan memiliki solidaritas sosial yang kuat. Pembelajaran kooperatif merupakan suatu kelompokstrategi pengajaran yang melibatkan siswa bekerja secara berkolaborasi untuk mencapai tujuan bersama.

\section{Model Pembelajaran Kooperatif tipe Think Pair Share (TPS)}

Wahyuningtyas (2016: 25) menuliskan bahwa salah satu tipe model pembelajaran kooperatif adalah think pair share. Pembelajaran kooperatif tipe think pair share ini dikembangkan oleh Frank Lyman pada tahun 1985. Think pair share memiliki prosedur yang ditetapkan secara eksplisit untuk memberi siswa waktu lebih banyak untuk berpikir, menjawab dan saling membantu satu sama lain.

Istarani (2012: 68) menuliskan langkah-langkah pelaksanaan Think pair share adalah sebagai berikut: (a) Guru menyampaikan inti materi dan kompetensi yang ingin dicapai. (b) Peserta didik diminta untuk berpikir tentang materi/permasalahan yang disampaikan guru. (c) Peserta didik 
Fibri Rakhmawati \& Wisnu Syahputra: Perbedaan Kemamupuan Penalaran dan Komunikasi Matematis Siswa yang Diajar dengan Model Pembelajaran Kooperatif Tipe Think Pair Share (TPS) dan Group Investigation (GI)

diminta berpasangan dengan teman sebelahnya (kelompok 2 orang) dan mengutarakan hasil pemikiran masing-masing. (d) Guru memimpin hasil plano kecil diskusi, tiap kelompok mengemukakan hasil diskusinya. (e) Berawal dari kegiatan tersebut, guru mengarahkan pembicaraan pada pokok permasalahan dan menambah materi yang belum diungkapkan para peserta didik. (f) Guru memberi kesimpulan. (g) Penutup.

\section{Model Pembelajaran Kooperatif tipe Group Investigation (GI)}

Kurniasih dan Sani (2015: 71) menyatakan bahwa model pembelajaran Group Investigation (GI) adalah salah satu bentuk model pembelajaran kooperatif yang memiliki titik tekan pada partisipasi dan aktivitas siswa untuk mencari sendiri materi atau segala sesuatu mengenai mata pelajaran yang akan dipelajari.Sujatna dalam buku Model Pembelajaran menyatakan bahwa metode Group Investigation (GI) merupakan pembelajaran kooperatif yang melibatkan kelompok-kelompok kecil dimana siswa bekerja menggunakan inquiri kooperatif, perencanaan, proyek dan diskusi kelompok, dan kemudian mempresentasikan penemuan mereka kepada kelas. Metode yang digunakan adalah metode diskusi yaitu dalam model pembelajaran Group Investigation (GI) siswa yang telah dibagi menjadi beberapa kelompok diarahkan untuk berdiskusi, dan diakhir pembelajaran dilakukan evaluasi secara individu atau kelompok, atau keduanya.

Istarani (2012: 86) menuliskan langkah-langkah pembelajaran dengan menggunakan model pembelajaran Group Investigation (GI) antara lain: (a) Guru membagi kelas dalam beberapa kelompok heterogen. (b) Guru menjelaskan maksud pembelajaran dan tugas kelompok. (c) Guru memanggil ketua kelompok dan setiap kelompok mendapat tugas satu materi/tugas yang berbeda dari kelompok lain. (d) Masing-masing kelompok membahas materi yang sudah ada secara kooperatif dan bersifat penemuan. (e) Setelah selesai berdiskusi, juru bicara kelompok menyampaikan hasil pembahasan kelompok. (f) Guru memberikan penjelasan singkat sekaligus memberikan kesimpulan. (g) Evaluasi. (h) Penutup.

\section{Metode Penelitian}

\section{Jenis Penelitian}

Penelitian ini menggunakan pendekatan kuantitatif yaitu merupakan penelitian eksprimen semu. Pelaksaanaannya melibatkan dua kelompok eksperimen, yaitu siswa yang diajarkan dengan menggunakan model pembelajaran kooperatif tipe Think Pair Share (TPS) yang disebut sebagai kelas eksperimen A dan siswa diajarkan dengan menggunakan model pembelajaran kooperatif tipe Group Investigation (GI) yang disebut sebagai kelas eksperimen B. Desain penelitian ini adalah sebagai berikut:

\section{Tabel 1. Desain Penelitian}

\begin{tabular}{lcc}
\hline \multirow{2}{*}{ Kemampuan } & \multicolumn{2}{c}{ Pembelajaran } \\
\cline { 2 - 3 } & Kooperatif Tipe TPS $\left(\mathbf{A}_{\mathbf{1}}\right)$ & Kooperatif Tipe GI (A) \\
\hline Penalaran Matematis $\left(\mathrm{B}_{1}\right)$ & $\mathrm{A}_{1} \mathrm{~B}_{1}$ & $\mathrm{~A}_{2} \mathrm{~B}_{1}$ \\
Komunikasi Matematis $\left(\mathrm{B}_{2}\right)$ & $\mathrm{A}_{1} \mathrm{~B}_{2}$ & $\mathrm{~A}_{2} \mathrm{~B}_{2}$ \\
\hline
\end{tabular}

\section{Waktu dan Tempat Penelitian}

Penelitian dilaksanakan pada semester II tahun pelajaran 2018-2019 pada bulan April 2019. Penelitian ini dilaksanakan pada bab keempat dari empat bab yaitu integral yang dilakukan sebanyak empat kali pertemuan. Sebelum penelitian dimulai, peneliti mengawali dengan observasi untuk menemukan permasalahan yang dihadapi dalam proses pembelajaran. Observasi dilaksanakan pada bulan Januari 2019. Sedangkan tempat penelitian ini dilaksanakan di MAN 1 Medan yang berlokasi di Jalan Williem Iskandar No. 67, Sidorejo, Medan Tembung, Kota Medan, Sumatera Utara 20222. 


\section{Subjek Penelitian/Populasi dan Sampel}

Populasi dalam penelitian ini adalah seluruh siswa kelas XI MIA di MAN 1 Medan, tahun pembelajaran 2018-2019 yang berjumlah 372 siswa. Sampel yang digunakan oleh peneliti adalah seluruh kelas XI MIA 6 dan kelas XI MIA 7 MAN 1 Medan untuk dijadikan kelas eksperimen yang ditentukan dengan cara Cluster Random Sampling. Jumlah dari populasi adalah 372 dari kelas XI MIA 6 sebanyak 45 siswa dan dari kelas XI MIA 7 sebanyak 45 siswa.

\section{Prosedur}

Desain yang digunakan pada penelitian ini ialah desain faktorial dengan taraf $2 \times 2$.Dalam desain ini masing-masing variabel bebas diklasifikasikan menjadi 2 (dua) sisi, yaitu Pembelajaran Kooperatif Tipe Think Pair Share $\left(\mathrm{A}_{1}\right)$ dan Pembelajaran Kooperatif Tipe Group Investigation $\left(\mathrm{A}_{2}\right)$.Sedangkan variabel terikatnya diklasifikasikan menjadi Kemampuan Penalaran $\left(\mathrm{B}_{1}\right)$ dan Kemampuan Komunikasi Matematika (B2).

\section{Data, Intrumen, dan Teknik Pengumpulan Data}

Data yang digunakan pada penelitian ini adalah data yang berasal dari tes kemampuan penalaran matematis siswa dan kemampuan komunikasi matematis siswa. Tes kemampuan penalaran matematis digunakan untuk mengukur kemampuan penalaran matematis baik sebelum (pre-test) dan sesudah perlakuan diberikan(post-test). Tes kemampuan penalaran berupa soalsoal berbentuk uraian yang terdiri atas 4 soal dan berkaitan dengan materi yang di eksperimenkan. Sedangkan tes kemampuan komunikasi matematis siswa diukur melalui kemampuan siswa dalam menyelesaikan soal-soal yang mengandung indikator-indikator kemampuan komunikasi matematis sebanyak 4 soal Tes ini berupa soal-soal bentuk uraian berkaitan dengan materi yang akan dieksperimenkan. Tes ini diberikan sebelum (pre-test) dan sesudah perlakuan (post-test) untuk kelompok eksperimen 1 dan kelompok eksperimen 2. Hasil validitas tes kemampuan penalaran dan komunikasi matematis adalah sebagai berikut:

Tabel 2. Validitas Soal Kemampuan Penalaran dan Komunikasi Matematika

\begin{tabular}{ccccc}
\hline No & $\boldsymbol{r}_{\boldsymbol{x y}}$ & $\boldsymbol{r}_{\text {hitung }}$ & $\boldsymbol{r}_{\text {tabel }}$ & Interpretasi \\
\hline 1 & 0.546 & 0.379 & 0.337 & Valid \\
2 & 0.588 & 0.427 & 0.337 & Valid \\
3 & 0.551 & 0.416 & 0.337 & Valid \\
4 & 0.759 & 0.671 & 0.337 & Valid \\
5 & 0.577 & 0.463 & 0.337 & Valid \\
6 & 0.533 & 0.386 & 0.337 & Valid \\
7 & 0.587 & 0.431 & 0.337 & Valid \\
8 & 0.684 & 0.463 & 0.337 & Valid \\
\hline
\end{tabular}

Perhitungan reliabilitas dengan rumus alpha, dari 8 butir soal tes yang terdiri dari soal tes kemampuan penalaran (nomor soal 1-4) dan kemampuan komunikasi matematis (nomor soal 58) yang telah diuji, diperoleh koefisien kemampuan penalaran dan komunikasi matematis adalah 0,745578662 dikatakan reliabilitas tinggi.

\section{Teknik Analisis Data}

Sebelum model pembelajaran kooperatif tipe TPS dan GI diterapkan, siswa diberikan pre-test terlebih dahulu. Pre-test ini diberikan pada kedua kelas yaitu kelas eksperimen I dan kelas eksperimen II. Tujuan pemberian pre-test adalah untuk melihat kemampuan awal siswa yang memiliki kemampuan penalarandan kemampuan komunikasi matematis siswa juga untuk mengetahui tingkat pemahaman siswa pada materi Integral.

Untuk melihat tingkat kemampuan matematis siswa yang menggunakan model kooperatif tipe TPS dan model pembelajaran kooperatif tipe GI, data dianalisis dengan statistik deskriptif dari soal pre test dan post test. Sedangkan untuk melihat perbedaan kemampuan penalaran dan 
Fibri Rakhmawati \& Wisnu Syahputra: Perbedaan Kemamupuan Penalaran dan Komunikasi Matematis Siswa yang Diajar dengan Model Pembelajaran Kooperatif Tipe Think Pair Share (TPS) dan Group Investigation (GI)

kemampuan komunikasi matematis siswa data dianalisis dengan statistik inferensial yaitu dengan menggunakan teknik analisis varians (ANAVA) dua jalur (two way).

\section{Hasil Penelitian dan Pembahasan}

1. Hasil

Hasil nilai pre-test kemampuan penalaran dan kemampuan komunikasi matematis siswa pada kelas eksperimen I dan kelas eksperimen II dapat dideskripsikan seperti terlihat pada tabel di bawah ini:

Tabel 3. Data Pre-test Kemampuan Penalaran dan Kemampuan Komunikasi MatematisSiswa pada Kelas Eksperimen I dan Eksperimen II

\begin{tabular}{cllll}
\hline Sumber Statistik & \multicolumn{2}{c}{ A1 } & N & A2 \\
\hline B1 & N & 45 & Mean & 29,6178 \\
& Mean & 29,68 & St. Dev & 9,41023 \\
& St. Dev & 9,15904 & Var & 88,5524 \\
& Var & 83,888 & N & 45 \\
& N & 45 & Mean & 28,2489 \\
Mean & 29,2444 & St. Dev & 10,8743 \\
& St. Dev & 10,9189 & Var & 118,249 \\
\hline
\end{tabular}

Selanjutnya, hasil post test dari kemampuan penalaran dan kemampuan komunikasi matematis siswa yang diajar dengan menggunakan model pembelajaran kooperatif tipe TPS dan model pembelajaran kooperatif tipe GI dapat dideskripsikan seperti terlihat pada tabel di bawah ini.

Tabel 4. Data Hasil Post-test Kemampuan Penalaran dan Kemampuan Komunikasi Matematis Siswa Pada Kelas Eksperimen Yang Diajar Dengan Model Pembelajaran Kooperatif Tipe Think Pair Share (TPS) dan Group Investigation (GI)

\begin{tabular}{ccccc}
\hline Sumber Statistik & \multicolumn{3}{c}{ A1 } & A2 \\
\hline & N & 45 & N & 45 \\
B1 & Mean & 83,32222 & Mean & 78,8422 \\
& St. Dev & 11,33767 & St. Dev & 11,8675 \\
& Var & 128,5427 & Var & 140,838 \\
\hline & $\mathrm{N}$ & 45 & $\mathrm{~N}$ & 45 \\
& Mean & 78,2356 & Mean & 76,4222 \\
& St. Dev & 11,8987 & St. Dev & 11,8629 \\
& Var & 141,578 & Var & 140,729 \\
\hline
\end{tabular}

Sebelum melakukan uji hipotesis dengan analisis varians (ANAVA) terhadap hasil tes siswa perlu dilakukan uji persyaratan data meliputi analisis normalitas dan homogenitas dari distribusi data hasil tes yang telah dikumpulkan. Hasil uji normalitas dan homogenitas disajikan pada tabel masing-masing berikut: 
Tabel 5. Hasil Uji Normalitas dari Masing-masing Sub Kelompok

\begin{tabular}{cccc}
\hline Kelompok & L - hitung & L - tabel $\boldsymbol{\alpha}=\mathbf{0 , 0 5}$ & Kesimpulan \\
\hline $\mathrm{A}_{1} \mathrm{~B}_{1}$ & 0,126 & & Normal \\
$\mathrm{A}_{2} \mathrm{~B}_{1}$ & 0,123 & \multirow{2}{*}{0,132} & Normal \\
$\mathrm{A}_{1} \mathrm{~B}_{2}$ & 0,130 & & Normal \\
$\mathrm{A}_{2} \mathrm{~B}_{2}$ & 0,113 & & Normal \\
\hline $\mathrm{A}_{1}$ & 0,081 & & Normal \\
$\mathrm{A}_{2}$ & 0,90 & 0,093 & Normal \\
$\mathrm{B}_{1}$ & 0,056 & & Normal \\
$\mathrm{B}_{2}$ & 0,090 & & Normal \\
\hline
\end{tabular}

Tabel 6. Hasil Uji Homogenitas

\begin{tabular}{|c|c|c|c|c|c|c|c|c|}
\hline Kel & db & $\mathbf{S i}^{2}$ & db.Si ${ }^{2}$ & $\begin{array}{c}\log \\
\left(\mathbf{S i}^{2}\right)\end{array}$ & db. $\log \mathrm{Si}^{2}$ & $\mathbf{X}^{2}$ hitung & $\mathbf{X}^{2}$ tabel & Keputusan \\
\hline$A_{1} B_{1}$ & 44 & 128,543 & 5655,88 & 2,109 & 92,798 & \multirow{4}{*}{0,14048} & \multirow{4}{*}{7,815} & \multirow{4}{*}{ Homogen } \\
\hline$A_{1} B_{2}$ & 44 & 141,578 & 6229,43 & 2,151 & 94,644 & & & \\
\hline$A_{2} B_{1}$ & 44 & 140,838 & 6196,87 & 2,149 & 94,544 & & & \\
\hline$A_{2} B_{2}$ & 44 & 140,729 & 6192,08 & 2,148 & 94,529 & & & \\
\hline $\mathrm{A}_{1}$ & 89 & 140,0842 & 12467,5 & 2,146 & 191,029 & \multirow{2}{*}{0,0004} & \multirow{4}{*}{3,841} & \multirow{4}{*}{ Homogen } \\
\hline $\mathrm{A}_{2}$ & 89 & 140,6824 & 12520,7 & 2,148 & 191,193 & & & \\
\hline $\mathrm{B}_{1}$ & 89 & 138,251 & 12304,3 & 2,141 & 190,519 & \multirow{2}{*}{0,00529} & & \\
\hline $\mathrm{B}_{2}$ & 89 & 140,399 & 12495,5 & 2,147 & 191,115 & & & \\
\hline
\end{tabular}

Setelah dilakukan analisis varians (ANAVA) melalui uji $\mathrm{F}$ dan koefisien $\mathrm{Q}_{\text {hitung, maka }}$ masing-masing hipotesis dan pembahasan dapat dijabarkan sebagai berikut:

a. Hipotesis Pertama

Ho : Tidak terdapat perbedaan kemampuan penalaran dan kemampuan komunikasi matematis siswa yang diajardengan model pembelajaran kooperatif tipe Think Pair Share (TPS) dan model pembelajaran kooperatif tipe Group Investigation (GI) pada materi pokok Integral di kelas XI MIA MAN 1 Medan Tahun Pembelajaran 20182019.

Ha: Terdapat perbedaan kemampuan penalaran dan kemampuan komunikasi matematis siswa yang diajardengan model pembelajaran kooperatif tipe Think Pair Share (TPS) dan model pembelajaran kooperatif tipe Group Investigation (GI) pada materi pokok Integral di kelas XI MIA MAN 1 Medan Tahun Pembelajaran 2018-2019.

Berdasarkan hasil analisis uji $\mathrm{F}$, diperoleh nilai $\mathrm{F}_{\text {hitung }}=3,286$ dan diketahui nilai pada $\mathrm{F}_{\text {tabel }}$ pada taraf $(\alpha=0,05)=3,047$. Selanjutnya dengan membandingkan $F_{\text {hitung }}$ dengan $F_{\text {tabel }}$ untuk menentukan kriteria penerimaan dan penolakan Ho,diketahui bahwa nilai koefisien $\mathrm{F}_{\text {hitung }}>$ $\mathrm{F}_{\text {tabel }}$. Berdasarkan ketentuan sebelumnya maka menerima $\mathrm{H}_{\mathrm{a}}$ dan menolak $\mathrm{H}_{0}$.

b. Hipotesis Kedua

Ho : Tidak terdapat perbedaan kemampuan penalaran matematis siswa yang diajardengan model pembelajaran kooperatif tipe Think Pair Share (TPS) dan model pembelajaran kooperatif tipe Group Investigation (GI) pada materi pokok Integral di kelas XI MIA MAN 1 Medan Tahun Pembelajaran 2018-2019.

Ha : Terdapat perbedaan kemampuan penalaran matematis siswa yang diajar dengan model pembelajaran kooperatif tipe Think Pair Share (TPS) dan model pembelajaran kooperatif tipe Group Investigation (GI) pada materi pokok Integral di kelas XI MIA MAN 1 Medan Tahun Pembelajaran 2018-2019.

Berdasarkan hasil analisis uji $\mathrm{F}$ diperoleh nilai $\mathrm{F}_{\text {hitung }}=3,353$, diketahui nilai pada $\mathrm{F}_{\text {tabel }}$ pada taraf $(\alpha=0,05)=2,706$. Selanjutnya dengan membandingkan $F_{\text {hitung }}$ dengan $F_{\text {tabel }}$ untuk 
Fibri Rakhmawati \& Wisnu Syahputra: Perbedaan Kemamupuan Penalaran dan Komunikasi Matematis Siswa yang Diajar dengan Model Pembelajaran Kooperatif Tipe Think Pair Share (TPS) dan Group Investigation (GI)

menentukan kriteria penerimaan dan penolakan Ho,diketahui bahwa nilai koefisien $\mathrm{F}_{\text {hitung }}>\mathrm{F}_{\text {tabel }}$ berdasarkan ketentuan sebelumnya maka menolak Ho dan menerima Ha. Selanjutnya dilakukan uji Tuckey, Berdasarkan uji Tuckey diperoleh $\mathrm{Q}_{3}\left(\mathrm{~A}_{1} \mathrm{~B}_{1}\right.$ dan $\left.\mathrm{A}_{2} \mathrm{~B}_{1}\right)$ hitung $>\mathrm{Q}_{\text {tabel }}$ di mana $\mathrm{Q}_{\text {hitung }}=4,480$ dan $\mathrm{Q}_{\text {tabel }}=2,656$. Dengan demikian dapat disimpulkan bahwa secara keseluruhan hasil kemampuan penalaran matematis siswa yang diajar dengan model pembelajaran kooperatif tipe Think Pair Share (TPS) lebih baik daripada siswa yang diajar dengan model pembelajaran kooperatif tipe Group Investigation (GI) pada materi integral.

c. Hipotesis Ketiga

Ho : Tidak terdapat perbedaan kemampuan komunikasi matematis siswa yang diajardengan model pembelajarankooperatiftipeThink Pair Share (TPS) dan model pembelajarankooperatiftipeGroup Investigation (GI) padamateripokok Integral di kelas XI MIA MAN 1 Medan Tahun Pembelajaran 2018-2019.

Ha: Terdapat perbedaan kemampuan komunikasi matematis siswa yang diajardengan model pembelajarankooperatiftipeThink Pair Share (TPS) dan model pembelajarankooperatiftipeGroup Investigation (GI) padamateripokok Integral di kelas XI MIA MAN 1 Medan Tahun Pembelajaran 2018-2019.

Berdasarkan hasil analisis uji $\mathrm{F}$ diperoleh nilai $\mathrm{F}_{\text {hitung }}=0,524$, diketahui nilai pada $\mathrm{F}_{\text {tabel }}$ pada taraf $(\alpha=0,05)=2,706$. Selanjutnya dengan membandingkan $F_{\text {hitung }}$ dengan $F_{\text {tabel }}$ untuk menentukan kriteria penerimaan dan penolakan Ho, diketahui bahwa nilai koefisien $\mathrm{F}_{\text {hitung }}>\mathrm{F}_{\text {tabel }}$ berdasarkan ketentuan sebelumnya maka menerima Ho dan menolak Ha. Selanjutnya dilakukan uji Tuckey, Berdasarkan uji Tuckey yang dilakukan diperoleh $\mathrm{Q}_{4}\left(\mathrm{~A}_{1} \mathrm{~B}_{2} \text { dan } \mathrm{A}_{2} \mathrm{~B}_{2}\right)_{\text {hitung }}<\mathrm{Q}_{\text {tabel }}$ di mana $\mathrm{Q}_{\text {hitung }}=1,813$ dan $\mathrm{Q}_{\text {tabel }}=2,656$. Dengan demikian dapat disimpulkan bahwa secara keseluruhan hasil kemampuan penalaran matematis siswa yang diajar dengan model pembelajaran kooperatif tipe Think Pair Share (TPS) tidak lebih baik daripada siswa yang diajar dengan model pembelajaran kooperatif tipe Group Investigation (GI) pada materi integral.

d. Hipotesis Keempat

Ho: Tidak terdapat interaksiantara model pembelajaran dengan kemampuan matematis siswa padamateripokok Integral di kelas XI MIA MAN 1 Medan Tahun Pembelajaran 2018-2019.

Ha: Terdapat interaksiantara model pembelajaran dengan kemampuan matematis siswa padamateripokok Integral di kelas XI MIA MAN 1 Medan Tahun Pembelajaran 20182019.

Berdasarkan hasil analisis uji $\mathrm{F}$ diperoleh nilai $\mathrm{F}_{\text {hitung }}=0,590$ dan $\mathrm{F}_{\text {tabel }}$ pada taraf $(\alpha=$ $0,05)=3,047$ untuk menentukan kriteria penerimaan dan penolakan Ho. Selanjutnya dengan melihat nilai $F_{\text {hitung }}$ sebagai hasil interaksi untuk menentukan kriteria penerimaan dan penolakan $\mathrm{H}_{0}$, dan diketahui bahwa nilai INT. A $\mathrm{X} \mathrm{B} \neq 0$. Berdasarkan ketentuan sebelumnya maka menerima $\mathrm{H}_{0}$ dan menolak $\mathrm{H}_{\mathrm{a}}$. Dapat dikatakan bahwa: Tidak terdapat interaksi antara model pembelajaran yang di gunakan terhadap kemampuan penalaran dan kemampuan komunikasi matematis siswa pada materi integral.

\section{Pembahasan}

Temuan hipotesis pertama menyatakan terdapat perbedaan kemampuan penalaran dan kemampuan komunikasi matematis siswa yang diajar dengan model pembelajaran kooperatif tipe Think Pair Share (TPS) dan Group Investigation (GI) yaitu kemampuan penalaran dan kemampuan komunikasi matematis siswa yang diajar dengan model pembelajaran kooperatif tipe Think Pair Share (TPS) lebih baik daripada siswa yang diajar dengan model pembelajaran kooperatif tipe Group Investigation (GI) pada materi pokok Integral kelas XI MIA MAN 1 Medan. Hal ini disebabkan karena ilmu matematika yang dimiliki seseorang akan berkembang jika dalam kehidupan sehari-hari, baik dalam menalar hingga mengkomunikasikan bahasa matematika dengan baik. Hal ini menunjukkan bahwa siswa harus memiliki kemampuan awal 
untuk melakukan proses penyelesaian masalah, untuk membangun dan meningkatkan kemampuan penalaran dan kemampuan komunikasi matematis dengan modal kognitif yang telah dimiliki sebelumnya. Sejalan dengan hasil penelitian yang dilakukan Slavin, bahwa penggunaan pembelajaraan kooperatif dapat meningkatkan prestasi belajar siswa dan dapat sekaligus meningkatkan hubungan sosial, menumbuhkan sikap toleransi, dan menghargai pendapat orang lain. Salah satu kelebihan dari pembelajaran kooperatif tipe TPS dalam bukunya Istarani yaitu dapat meningkatkan daya nalar, daya kritis siswa, daya imajinasi dan analisis terhadap suatu permasalahan. Sehingga siswa dapat menyelesaikan masalah yang diberikan dengan lebih baik. Hal tersebut yang menjadikan hasil tes kemampuan siswa lebih baik dengan menggunakan model pembelajaran kooperatif tipe TPS.

Temuan hipotesis kedua menyatakan bahwa terdapat perbedaan kemampuan penalaran matematis siswa yang diajar dengan model pembelajaran kooperatif tipe Think Pair Share (TPS) dan Group Investigation (GI) yaitukemampuan penalaran matematis siswa yang diajar dengan model pembelajaran kooperatif tipe Think Pair Share (TPS) lebih baik daripada siswa yang diajar dengan model pembelajaran kooperatif tipe Group Investigation (GI) pada materi pokok Integral kelas XI MIA MAN 1 Medan. Salah satu kelebihan dari pembelajaran kooperatif tipe TPS dalam bukunya Istarani yaitu dapat meningkatkan daya nalar, daya kritis siswa, daya imajinasi dan analisis terhadap suatu permasalahan. Sehingga siswa dapat menyelesaikan masalah yang diberikan dengan lebih baik.Bahwa dalam pembelajaran dengan model pembelajaran kooperatif tipe TPS, siswa dituntut untuk berpikir, kemudian bertukar pikiran dengan pasangannya dan selanjutnya berbagi ke rekan-rekan kelasnya. Sehingga memudahkan siswa yang belum paham dengan materi Integral karena mereka saling bertukar pendapat untuk menyelesaiakan suatu masalah yang diberikan. Hal demikianlah yang membuat siswa cepat tanggap dan menalar dalam menyelesaiakn permasalahan yang diberikan.

Temuan hipotesis ketiga menyatakan bahwa model pembelajaran kooperatif tipe Think Pair Share (TPS) dan Group Investigation (GI0 yaitu kemampuan komunikasi matematis siswa yang diajar dengan model pembelajaran kooperatif tipe Think Pair Share (TPS) tidak lebih baik daripada siswa yang diajar dengan model pembelajaran kooperatif tipe Group Investigation (GI) pada materi pokok Integral kelas XI MIA MAN 1 Medan. Hal ini disebabkan karena faktor dari siswa sendiri yang masih ada siswa yang kurang dalam menghubungkan ide matematis kedalam bentuk gambar/grafik. Ada beberapa siswa yang masih bingung dalam menggambar grafik kartesius dan tidak menuliskan lengkap titik-titik koordinatnya.

Temuan hipotesis keempat adalah tidak terdapat interaksi yang signifikan antara model pembelajaran terhadap kemampuan penalaran dan kemampuan komunikasi matematis siswa pada materi Integral kelas XI MIA MAN 1 Medan. Hal ini disinyalir dari perbedaan rata-rata kemampuan penalaran dan komunikasi matematis siswa pada model pembelajaran kooperatif tipe TPS dan rata-rata kemampuan penalaran dan komunikasi matematis siswa pada model pembelajaran kooperatif tipe GI.

\section{E. Simpulan}

Simpulan dari penelitian ini adalah terdapat perbedaan antara kemampuan penalaran dan kemampuan komunikasi matematis siswa yang diajar dengan model pembelajaran kooperatif tipe Think Pair Share (TPS) dan Group Investigation (GI) pada materi pokok Integral kelas XI MIA MAN 1 Medan.

\section{DAFTAR PUSTAKA}

Handayani, Ayu. (2014). Analisis kemampuan komunikasi matematis siswa melalui pendekatan pendidikan matematika realistik (pmr) bagi siswa kelas VII MTsN Lubuk Pakam Buaya Padang tahun pelajaran 2013/2014. Jurnal Pendidikan Matematika, 3(2), 1-6.

Hasratuddin. (2015). Mengapa harus belajar matematika?. Medan: Perdana Publishing. 
Fibri Rakhmawati \& Wisnu Syahputra: Perbedaan Kemamupuan Penalaran dan Komunikasi Matematis Siswa yang Diajar dengan Model Pembelajaran Kooperatif Tipe Think Pair Share (TPS) dan Group Investigation (GI)

Hendriana, H., Rohaeti, E.E., \& Sumarmo, U. (2017). Hard skills dan soft skills matematik siswa. Bandung: Refika Aditama.

Istarani. (2012). 58 model pembelajaran inovatif. Medan: Media Pesada.

Kurniasih, Imas \& Sani, Berlin. (2015). Ragam pengembangan model pembelajaran untuk peningkatan profesionalitas guru. Yogyakarta: Kata Pena.

NCTM. (2000). Principles and standards for school mathematics. Reston, VA: National Concil of Teacher of Mathematics.

Ramdani, Yani. (2012). Pengembangan instrumen dan bahan ajar untuk meningkatkan kemampuan komunikasi, penalaran, dan koneksi matematika dalam konsep integral. Jurnal Penelitian Pendidikan, 13(1), 44-52.

Rasyidin, A. \& Nur, W. (2011). Teori belajar dan pembelajaran. Medan: Perdana Publishing.

Rusman. (2010). Model-model pembelajaran. Depok: Rajagrafindo Persada.

Sugianto, S., Armanto, D., \& Harahap, M. B. (2014). Perbedaan penerapan model pembelajaran kooperatif tipe jigsaw dan STAD ditinjau dari kemampuan penalaran dan komunikasi matematis siswa. Jurnal Didaktik Matematika, 1(1), 96-128.

Trianto. (2014). Mendesaian model pembelajaran inovatic, progresif dan kontekstual. Surabaya: Prenadamedia Group.

Wahyuningtyas, Erina Sri. (2016). Meningkatkan hasil belajar siswa melalui pemahaman konsep matematis siswa dengan menggunakan model pembelajaran kooperatif tipe think pair share di kelas VIII SMP. Jurnal Pendidikan Matematika, 4(1), 24-31. 